\section{Determining Freezing Injury from Changes in Chlorophyll Fluorescence in Potted Oleander Plants}

\author{
Julián Miralles-Crespo ${ }^{1}$ and Juan Antonio Martínez-López \\ Universidad Politécnica de Cartagena, Escuela Técnica Superior de Ingeniería \\ Agronómica, Departamento de Producción Vegetal, Paseo Alfonso XIII, 48, \\ 30203 Cartagena (Murcia), Spain
}

\section{José Antonio Franco-Leemhuis and Sebastián Bañón-Arias Unidad Asociada al CSIC de "Horticultura Sostenible en Zonas Áridas" (UPCT-CEBAS), Departamento de Producción Vegetal, Paseo Alfonso XIII, 48, 30203 Cartagena (Murcia), Spain}

Additional index words. gas exchange, plant injury, non-photochemical quenching, maximum photochemical efficiency of photosystem II, ornamental plant

\begin{abstract}
Physiological and biochemical indicators that reflect the responses of plants to chilling stress could be useful for identifying plant damage caused by freezing or other stresses. The objective of this study was to determine any relationship between changes in chlorophyll fluorescence and the appearance of visual symptoms resulting from freezing temperatures in two cultivars of oleander. In the least frost-sensitive cultivar (yellow oleander), freezing temperatures $\left(-4^{\circ} \mathrm{C}\right.$ for $\left.3 \mathrm{~h}\right)$ did not produce changes in the photochemical parameters. In the more frost-sensitive cultivar (pink oleander), non-photochemical quenching (NPQ) and the maximum photochemical efficiency of photosystem II $\left(F_{v} / F_{m}\right)$ decreased after the same freezing treatment. The first of these potential indicators remained low, whereas the second steadily recovered during the 4 months after freezing simulation. The results suggest that measuring chlorophyll fluorescence may provide a rapid method for assessing freezing injury in oleander.
\end{abstract}

In areas with a Mediterranean climate, frost can occur in the field in winter or early spring. The production of ornamental plants in the nursery may be affected by freezing temperatures, which can produce severe injuries in the plants. Although methods are generally available to define and measure freezing temperature stress, quantifying the effect of stress on the plant is more difficult, because it depends on two closely related factors: 1) the time scale of exposure; and 2) the developmental strategy of the species in question (Huner et al., 1998).

The primary photochemical reactions of photosystem II (PSII) and PSI occur on a much faster time scale than electron transport and metabolism, and the exposure of plants to light energy in excess of that required for photosynthesis results in an energy imbalance that generally leads to photoinhibition (Osmond, 1994). Chilling can disrupt all major components of photosynthesis, including thylakoid electron transport, the carbon reduction cycle, and the control of

\footnotetext{
Received for publication 24 Jan. 2011. Accepted for publication 13 Apr. 2011.

This research was supported by Agrupación Española de Entidades Aseguradoras de los Seguros Agrarios Combinados, S.A. (AGROSEGURO).

We thank Raquel Valdés and Paula Cánovas for their conscientious contribution to the experiment. ${ }^{1}$ To whom reprint requests should be addressed; e-mail julian.miralles@upct.es.
}

stomatal conductance $\left(g_{\mathrm{S}}\right)$ (Allen and Ort, 2001). To prevent damage on a time scale of minutes, organisms can acclimate in an PSII excitation pressure. They do this by reducing energy transfer efficiency to PSII, either by diverting energy from PSII to PSI through state transitions or by dissipating excess energy as heat through non-photochemical quenching. On a longer time scale, photosynthetic acclimation to high PSII excitation pressure may occur as a consequence of a reduction in PSII antenna size (Huner et al., 1998). These mechanisms avoid damage to photosystems but result in a decrease in photosynthesis (D'Ambrosio et al., 2006). Hence, chlorophyll fluorescence is a useful tool for detecting the sensitivity of plants to stress, because the technique estimates the relative changes in PSII excitation pressure of organisms exposed to changing environmental conditions (Adams et al., 1995; Smillie and Hetherington, 1983). It is also useful for quantifying the extent to which the stress has damaged the photosynthetic apparatus (Percival and Fraser, 2001).

Chlorophyll fluorescence technique has been used in several species as an indicator of plant sensitivity to environmental stresses such as salinity (Percival and Fraser, 2001; Percival et al., 2003; Smillie and Nott, 1979), drought (Percival and Sheriffs, 2002), heat (Hetherington et al., 1983; Percival, 2005; Yamada et al., 1996), chilling (Hakam et al., attempt to compensate for exposure to high
2000; Lurie et al., 1994; Percival and Henderson, 2003; Wilson and Greaves, 1990), and freezing (Forney et al., 2000; Zulini et al., 2010).

Several studies have indicated that reductions in chlorophyll fluorescence occur in plants at temperatures near their chilling threshold. Smillie and Nott (1979) reported that the decrease in chlorophyll fluorescence of leaves during rapid chilling at $0{ }^{\circ} \mathrm{C}$ can be used as an index of the chilling sensitivity of plant species. Khanizadeh et al. (2000) and Sthapit et al. (1995) suggested that chlorophyll fluorescence can be used for estimating the stress tolerance of strawberry and rice, respectively, which is useful in selecting resistant spring frost selections in breeding programs.

This investigation focuses on oleander, an evergreen shrub from the Mediterranean regions of southern Europe, which is of great importance in the commercial production of potted plants and is much appreciated for its ornamental value. The objective of this study was to characterize freezing-induced changes in chlorophyll fluorescence parameters of two cultivars of oleander with different degrees of sensitivity to freezing temperatures and relate these indicators with visual symptoms of freezing injury in leaves.

\section{Materials and Methods}

Plant material and growing conditions. Two experiments were carried out in 2009 and 2010. In both years, plants from rooted cuttings in June of two oleander cultivars (Nerium oleander L. 'Yellow' and 'Pink') were cultivated in brown polyvinyl chloride pots of $2.8 \mathrm{~L}$ volume, $17 \mathrm{~cm}$ upper internal diameter, and $16 \mathrm{~cm}$ height. The pots were filled with a mixture of coconut fiber-bark and perlite $(4 / 1, v / v)$ and placed in an openair plot of $100 \mathrm{~m}^{2}$ at the Experimental AgroFood Station of the Polytechnic University of Cartagena, (lat. $37^{\circ} 35^{\prime} \mathrm{N}$, long. $0^{\circ} 59^{\prime} \mathrm{W}$ ). The pots were placed on a metal grille with a $16 \times 16-\mathrm{cm}$ mesh that kept them off the ground by solid blocks $60 \times 40 \times 40 \mathrm{~cm}$. Both experiments began in the first week of October and finished in the first week of June. During the experiments, the temperature was taken from a Meteorological Station sited $100 \mathrm{~m}$ from the experimental plot. The temperatures in the open air during the experiment periods were 13.5 and $12.6{ }^{\circ} \mathrm{C}$ (minimum), 17.6 and $17.2{ }^{\circ} \mathrm{C}$ (average), and 22.4 and $21.8^{\circ} \mathrm{C}$ (maximum) in the first and second experiments, respectively.

The plants were irrigated using computercontrolled automated programmable equipment (irrigation head and fertilization; Xilema NX300 Hidroponic, Novedades Agrícolas, S.A., Spain) and each pot had one emitter $\left(2 \mathrm{~L} \cdot \mathrm{h}^{-1}\right)$ connected to one spaghetti tube. The irrigation volume was determined by noting when the leaching fraction reached $15 \%$ to $20 \%$ and the irrigation frequency by taking into account when pots had lost between $70 \%$ and $90 \%$ of easily available water in the substrate determined by weight. 
Fertilization was carried out by the irrigation head, and nutrients were provided at constant concentrations in the irrigation water: $100 \mathrm{~N}-13.1 \mathrm{P}-99.6 \mathrm{~K}-42.9 \mathrm{Ca}$ (ppm) and $\mathrm{pH} \approx 6.0$. This nutrient solution was made by mixing $\mathrm{KNO}_{3}, \mathrm{Ca}\left(\mathrm{NO}_{3}\right)_{2}, \mathrm{NH}_{4}\left(\mathrm{NO}_{3}\right)$, $\mathrm{K}\left(\mathrm{HPO}_{4}\right)$, and $\mathrm{HNO}_{3}$. The fertilizers added increased the irrigation water electrical conductivity (EC), which, before fertilization, had an EC of $1.2 \mathrm{dS} \cdot \mathrm{m}^{-1}$ and a $\mathrm{pH}$ of 7.3 by $\approx 0.7 \mathrm{dS} \cdot \mathrm{m}^{-1}$.

Freezing treatments. Freezing was simulated by placing seven potted oleanders per treatment in darkness in a freezing chamber (Deltafrio, Control S.L., Archena, Spain) measuring $2.70 \times 2.70 \times 2.80 \mathrm{~m}$ with an accuracy of $\pm 0.5^{\circ} \mathrm{C}$. Fans circulated the air to keep the temperature similar at the top and bottom of the chamber. In the first experiment (27 Jan. 2009), four freezing intensities were applied by maintaining the plants in independent chambers for $3 \mathrm{~h}$ at $-2,-3,-4$, and $-5{ }^{\circ} \mathrm{C}$. In the second experiment $(1 \mathrm{Feb}$. 2010), the frosted plants were kept for $3 \mathrm{~h}$ at a temperature of $-4{ }^{\circ} \mathrm{C}$. In both experiments, the plants were introduced in the chambers at a temperature of $5{ }^{\circ} \mathrm{C}$, which was then gradually lowered $\left(\approx 1{ }^{\circ} \mathrm{C}\right.$ every $\left.5 \mathrm{~min}\right)$ to reach the treatment temperatures. The relative humidity in the chamber ranged from $75 \%$ to $80 \%$ in both experiments. The control was non-frozen plants, which remained in the open air. After freezing, the plants were returned to the trial site and placed in their original localization for 4 months.

Gas exchange and chlorophyll fluorescence measurements. Net photosynthesis $\left(\mathrm{P}_{\mathrm{n}}\right)$ and $g_{\mathrm{S}}$ were measured at midday using a CIRAS-2 Portable Photosynthesis System (PP Systems, Amesbury, MA). The air flow rate through the cuvette was $200 \mathrm{~mL} \cdot \mathrm{min}^{-1}$ with a $\mathrm{CO}_{2}$ of 350 ppm, a vapor pressure deficit of $1.6 \mathrm{kPa}$, and a photosynthetic photon flux $(P P F)$ of 1500 $\mu \mathrm{mol} \cdot \mathrm{m}^{-2} \cdot \mathrm{s}^{-1}$.

Chlorophyll fluorescence of the same leaves was measured using a Pulse Modulated Fluorimeter FMS-2 (PP Systems International, Inc., Amesbury, MA) with a modulation beam of 2 and a gain of 50 . After darkening the leaves for $30 \mathrm{~min}$, the minimal fluorescence in the dark-adapted state $\left(\mathrm{F}_{0}\right)$ was recorded. A saturating pulse of radiation $\left(5000 \mu \mathrm{mol} \cdot \mathrm{m}^{-2} \cdot \mathrm{s}^{-1}\right)$ was then applied for $0.7 \mathrm{~s}$ to determine the maximal fluorescence in the dark-adapted state $\left(\mathrm{F}_{\mathrm{m}}\right)$, and the maximum quantum efficiency of PSII primary photochemistry $\left[\mathrm{F}_{\mathrm{v}} / \mathrm{F}_{\mathrm{m}}=\left(\mathrm{F}_{\mathrm{m}}-\mathrm{F}_{0}\right) / \mathrm{F}_{\mathrm{m}}\right]$ was determined. Then, the leaves were irradiated with actinic light $\left(400 \mu \mathrm{mol} \cdot \mathrm{m}^{-2} \cdot \mathrm{s}^{-1}\right)$ for $3 \mathrm{~min}$ to measure the steady-state fluorescence in the light $\left(\mathrm{F}_{\mathrm{s}}{ }^{\prime}\right)$. Afterward, the plants were exposed to radiation $\left(5000 \mu \mathrm{mol} \cdot \mathrm{m}^{-2} \cdot \mathrm{s}^{-1}\right)$ for $0.7 \mathrm{~s}$ to determine the maximal fluorescence yields in the light-adapted state $\left(\mathrm{F}_{\mathrm{m}}{ }^{\prime}\right)$. After this, the actinic radiation was turned off. The quantum yield of PSII linear electron transport (éPSII) was calculated as éPSII = $\left(\mathrm{F}_{\mathrm{m}}{ }^{\prime}-\mathrm{F}_{\mathrm{s}}{ }^{\prime}\right) / \mathrm{F}_{\mathrm{m}}{ }^{\prime}$ according to Genty et al. (1989). The éPSII was used for the calculation of the linear electron transport rate (ETR) according to Krall and Edwards (1992): ETR = éPSII $\times$
$P P F D \times 0.84 \times 0.5$, where $P P F D$ represents the $P P F$ density incident on the leaf, 0.84 the assumed leaf absorbance, and 0.5 a factor implying the equal distribution of energy between PSII and PSI (Krall and Edwards, 1992). Stern-Volmer NPQ was expressed according to Bilger and Björkman (1990): $\mathrm{NPQ}=\left(\mathrm{F}_{\mathrm{m}}-\mathrm{F}_{\mathrm{m}}{ }^{\prime}\right) / \mathrm{F}_{\mathrm{m}}{ }^{\prime}$. The ratio between apparent ETR and net $\mathrm{P}_{\mathrm{n}}$ was calculated (Arena et al., 2008).

In the first experiment, only a final measurement (4 months after freezing simulation) was made of chlorophyll fluorescence at the cessation of the experiment on the first week of June, whereas in the second experiment, we also recorded this parameter and gas exchange $\left(\mathrm{P}_{\mathrm{n}}\right.$ and $\left.g_{\mathrm{S}}\right) 2 \mathrm{~h}$ after the freezing simulation and on Days 2, 4, 9, 17, 25 , and 120. Four extra measurements of chlorophyll fluorescence were measured on Days 1, 3, 7, and 11. Together, these measurements provided long-term information concerning the length of time that freezing simulation altered chlorophyll fluorescence and gas exchange. The measurements in Expt. 2 were taken in the same leaves, which were previously tagged. In all cases, measurements were made in the middle of the blade of six leaves (two from the top of the plant, two from the center, and two at the base) per plant, and for each plant, the average of six shots was determined. Five plants per treatment for each oleander cultivar were used for experimental purposes.

Index of freezing injury. To evaluate freezing temperature injury, we used an index of freezing injury, which was applied at the end of the experiments. The index ranged from 0 (no injury) to 4 (strong injury) based on the amount of leaf discoloration and leaf necrosis (leaf burn and red spots). Leaf discoloration percentage was calculated with a chlorophyll meter, SPAD-502 (Konica Minolta Sensing, Inc., Osaka, Japan). The measurements were performed in the same leaves as used for chlorophyll fluorescence determination. As a reference value, healthy control leaves were used and the discoloration was expressed as a percentage. Leaf necrosis percentage was calculated with the image analysis software for plant disease quantification ASSESS 2.0 (University of Manitoba, Winnipeg, Canada). Gradations in the rating scale were as follows: for leaf discoloration: less than $5 \%(0)$, less than $15 \%(1), 15 \%$ to $25 \%$ (2), $25 \%$ to $35 \%$ (3), and greater than $35 \%$ (4). For leaf necrosis: less than $1 \%(0)$, $1 \%$ to $5 \%$ (1), $5 \%$ to $10 \%$ (2), $10 \%$ to $15 \%$ (3), and greater than $15 \%$ (4). The individual ratings for leaf discoloration and leaf necrosis were averaged to give an overall freezing injury rating.

Statistical analysis and experimental design. The experimental design was a randomized

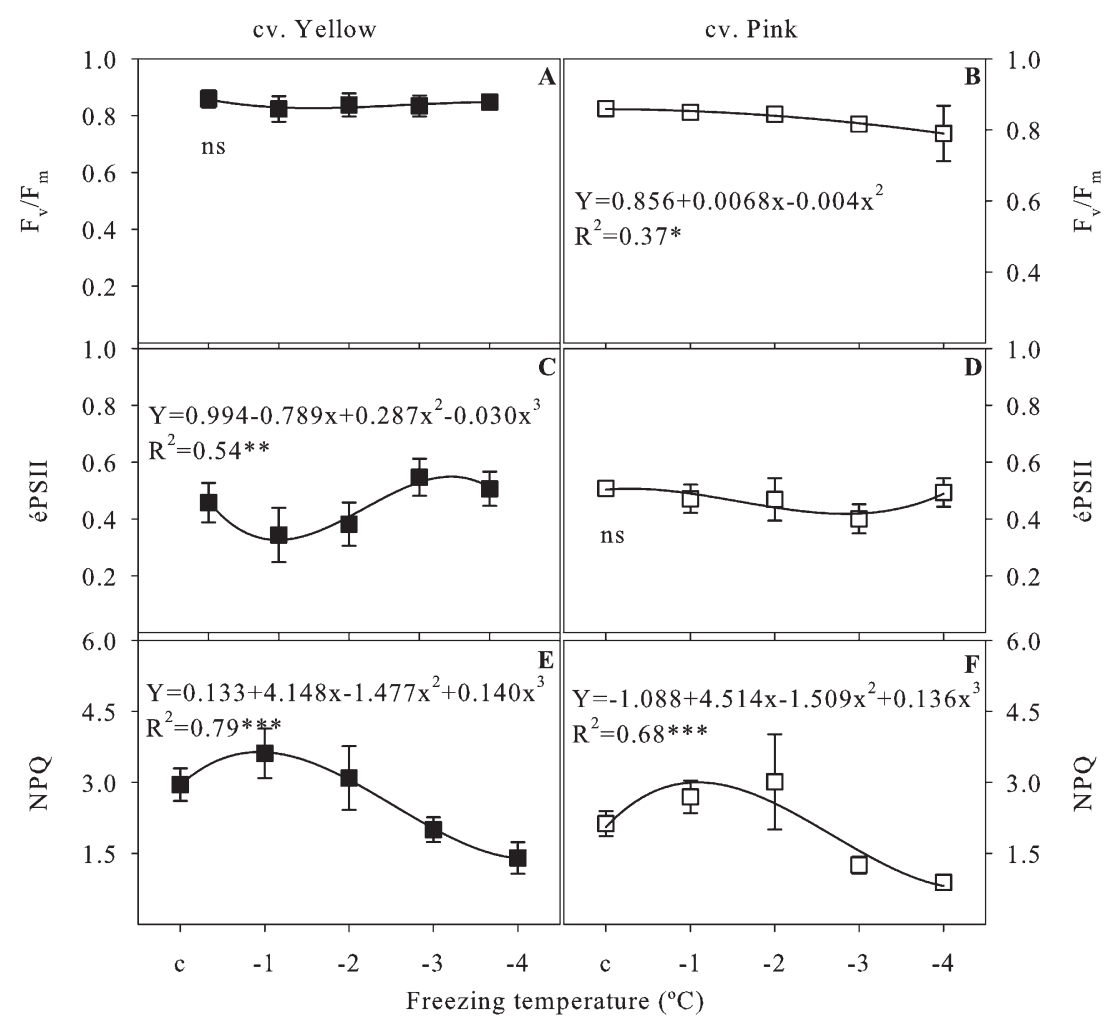

Fig. 1. Photochemical parameters in oleander leaves as a function of different intensities of freezing temperatures [c (control, no freezing), $-1,-2,-3$, and $-4{ }^{\circ} \mathrm{C}$ ] on 27 Jan. 2009. Measurements were made in the first week of June 2009. (A) Maximum photochemical efficiency of photosystem II (PSII) $\left(\mathrm{F}_{\mathrm{v}} / \mathrm{F}_{\mathrm{m}}\right)$ in $N$. oleander 'Yellow'; (B) $\mathrm{F}_{\mathrm{v}} / \mathrm{F}_{\mathrm{m}}$ in $N$. oleander 'Pink'; (C) quantum yield of PSII (éPSII) in $N$. oleander 'Yellow'; (D) éPSII in $N$. oleander 'Pink'; (E) non-photochemical quenching (NPQ) in $N$. oleander 'Yellow'; (F) NPQ in $N$. oleander 'Pink'. Vertical bars indicate SE $(\mathrm{n}=5)$. *Significant at $P<$ $0.05,{ }^{*}$ significant at $P<0.005,{ }^{* * *}$ significant at $P<0.0005$, and not significant (NS). 
complete block with five replications. The effects of freezing on chlorophyll fluorescence, gas exchange, and the freezing injury were analyzed by one-way analysis of variance using Statgraphics Plus for Windows (Manugistics Inc., Rockville, MD). Treatment means were separated by least significant difference test $(P<0.05)$. Ratios and percentages were arcsine $(\mathrm{x})^{1 / 2}$ transformed before statistical analysis to ensure homogeneity of variance. Regression analyses were performed using SigmaPlot 10.0 (Systat Software Inc., San Jose, CA).

\section{Results and Discussion}

Expt. 1. In the first experiment, we measured three photochemical parameters 4 months after the freezing simulations. Figure 1 shows how the $F_{v} / F_{m}$ and éPSII were similar between freezing treatments. The $\mathrm{F}_{\mathrm{v}} / \mathrm{F}_{\mathrm{m}}$ values of the two cultivars tested ranged from 0.80 to 0.84 (Fig. 1A-B), whereas éPSII was from 0.33 to 0.55 (Fig. 1C-D). These values indicate that the quantum yield and leaf photosynthetic system efficiency in frozen plants were to be expected from healthy plants (Percival, 2005). However, the correlation analysis showed that pink oleander plants tended to reduced $\mathrm{F}_{\mathrm{v}} / \mathrm{F}_{\mathrm{m}}$ at lower freezing temperatures (Fig. 1B). Thus, this correlation showed that $F_{v} / F_{m}$ could be related to freezing temperature injury in this cultivar, although it is not sufficiently accurate to provide a clear freezing temperature threshold below which visual injury results.

However, the NPQ of the oleanders stored at -4 and $-5{ }^{\circ} \mathrm{C}$ was lower than in non-frozen plants (control), whereas those of oleanders held -2 and $-3{ }^{\circ} \mathrm{C}$ remained statistically similar to the control (Fig. 1E-F). The physiological significance of a decreasing NPQ is a decline in the efficiency of heat dissipation, which is an essential mechanism in protecting the leaf from light-induced damage (Horton et al., 1996). Because temperatures of -4 and $-5^{\circ} \mathrm{C}$ caused freezing injury (Table 1), it may be hypothesized that the decrease in NPQ and freezing temperature damage were related. The moderate correlation in both cultivars showed that NPQ was the most sensitive chlorophyll coefficient for predicting freezing temperature damage (Fig. 1EF). However, when the pink cultivar was submitted to a temperature of $-3{ }^{\circ} \mathrm{C}$, plants also showed moderate injury (Table 1), whereas the NPQ value did not differ from the control (Fig. 1F). In this case, NPQ was not sensitive to plant damage. In this respect, we think that there was a decrease in NPQ when freezing temperature damage was strong, whereas moderate symptoms of freezing did not affect NPQ. The SE of the mean for NPQ values in the $-3{ }^{\circ} \mathrm{C}$ treatment in the pink oleander was higher than in other treatments (Fig. 1F), indicating the presence of both badly damaged and slightly damaged leaves; the threshold for freezing temperature damage in this cultivar would seem to be $\approx-3{ }^{\circ} \mathrm{C}$.

The lower visual damage in the yellow oleander may be related to the moderate correlations in both éPSII and NPQ as a function of freezing temperature. This cultivar had the ability to increase éPSII as NPQ decreased (Figs. 1C and 1E). So, lower thermal dissipation produced greater PSII activity (Huner et al., 1998), whereas the pink oleander did not modify its éPSII, thus indicating the occurrence of photodamage (Figs. 1D and 1F).

Expt. 2. The second experiment was performed the next year with the same cultivars and crop cycle. This experiment studied the effect of $-4{ }^{\circ} \mathrm{C}$ on chlorophyll fluorescence, because the results of the first experiment suggested that this temperature would injure both oleander varieties. However, immediately after freezing simulation, the pink oleander plants presented clear visible symptoms, whereas the yellow plants did not seem to be affected (Table 1). Temperatures close to $0{ }^{\circ} \mathrm{C}$ just before freezing simulation may have hard- ened the plants compared with those in the first experiment (Fig. 2A-B), as reported by Venema et al. (2000) in two Lycopersicon species. However, this response was useful for our study, because it allowed us to relate damaged and undamaged plants with photochemical parameters.

Two $h$ after freezing simulation, the éPSII in stressed pink oleander plants was low (Fig. 3B) but was slightly higher in non-frozen plants; at the same time, the photosynthetic activity of frozen plants was very low, whereas the control showed values of $\approx 5$ $\mu \mathrm{mol} \cdot \mathrm{m}^{-2} \cdot \mathrm{s}^{-1}$ (Fig. 3C). This photosynthetic depression just after freezing seems to be dependent on non-stomatal limitations, because the $g_{\mathrm{S}}$ in non-frozen and frozen plants was similar (Fig. 3E). In addition, the $g_{\mathrm{S}}$ of the non-frozen and frozen plants was similar throughout the study period, except on one

Table 1. Value of the freezing injury index in oleander plants at the end of the two experiments. ${ }^{2}$

\begin{tabular}{lcccccc}
\hline & \multicolumn{3}{c}{ First expt. } & & Second expt. \\
\cline { 2 - 6 } Cultivar & Control & $-2{ }^{\circ} \mathrm{C}$ & $-3{ }^{\circ} \mathrm{C}$ & $-4{ }^{\circ} \mathrm{C}$ & $-5{ }^{\circ} \mathrm{C}$ & \\
\hline Yellow & $0.0 \mathrm{a}$ & $0.0 \mathrm{a}$ & $1.1 \mathrm{~b}$ & $2.1 \mathrm{c}$ & $3.3 \mathrm{~d}$ \\
Pink & $0.0 \mathrm{a}$ & $0.0 \mathrm{a}$ & $2.6 \mathrm{~b}^{*}$ & $3.5 \mathrm{c}^{*}$ & $4.0 \mathrm{~d}^{*}$ & $1.2 \mathrm{~b}$ \\
\hline
\end{tabular}

${ }^{2}$ Freezing simulations were applied during $3 \mathrm{~h}$ on 27 Jan. 2009 (first experiment) and on 1 Feb. 2010 (second experiment). In each cultivar, different letters in the same row indicate statistically significant differences between means $(P<0.05)$ through the least significant difference test.

*Statistically significant differences between means $(P<0.05)$ of different cultivars in the same column.

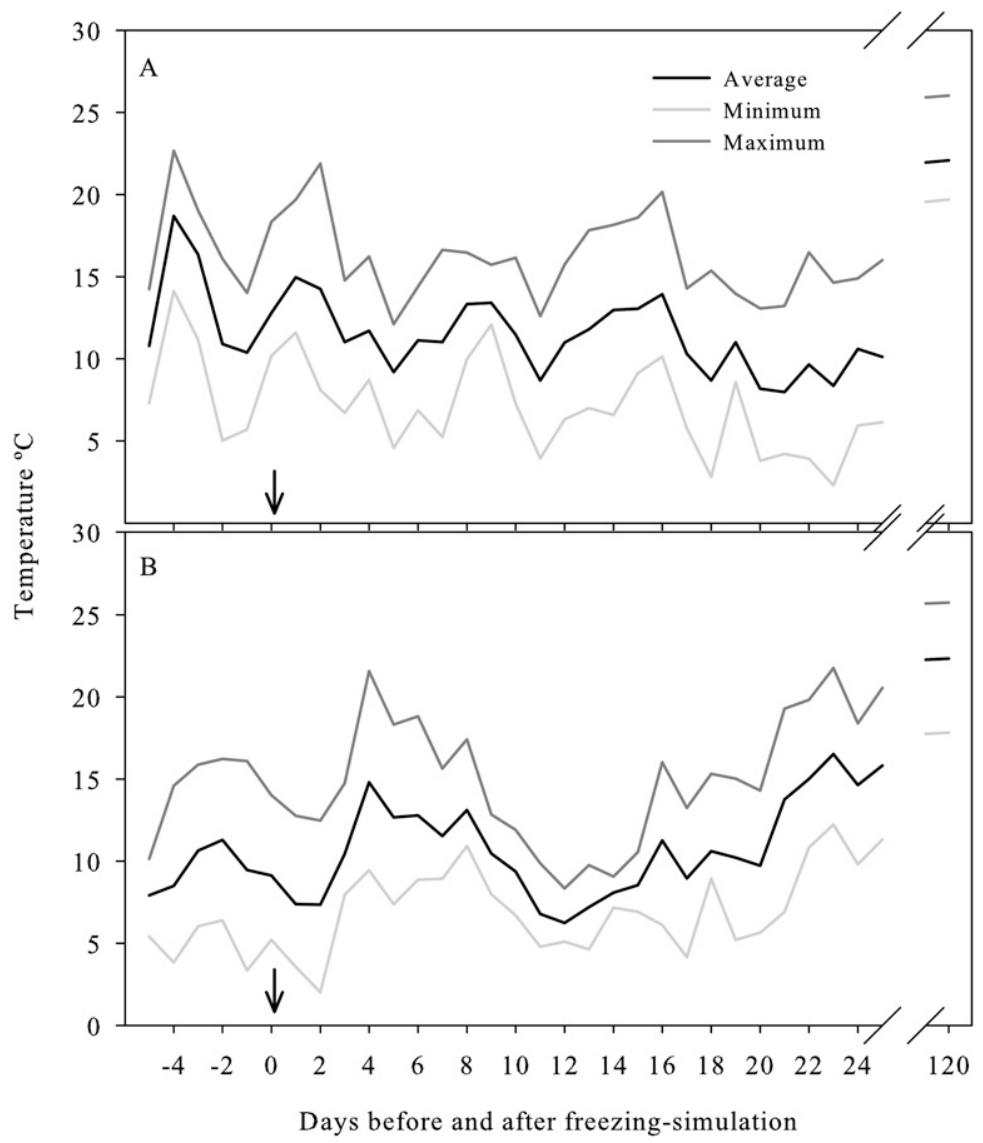

Fig. 2. Temperature evolution in the open air before and after the freezing-simulations: (A) first experiment, freezing treatments applied on $27 \mathrm{Jan} .2009$; (B) second experiment, freezing treatments applied on 1 Feb. 2010). The arrow indicates the freezing simulation day. 

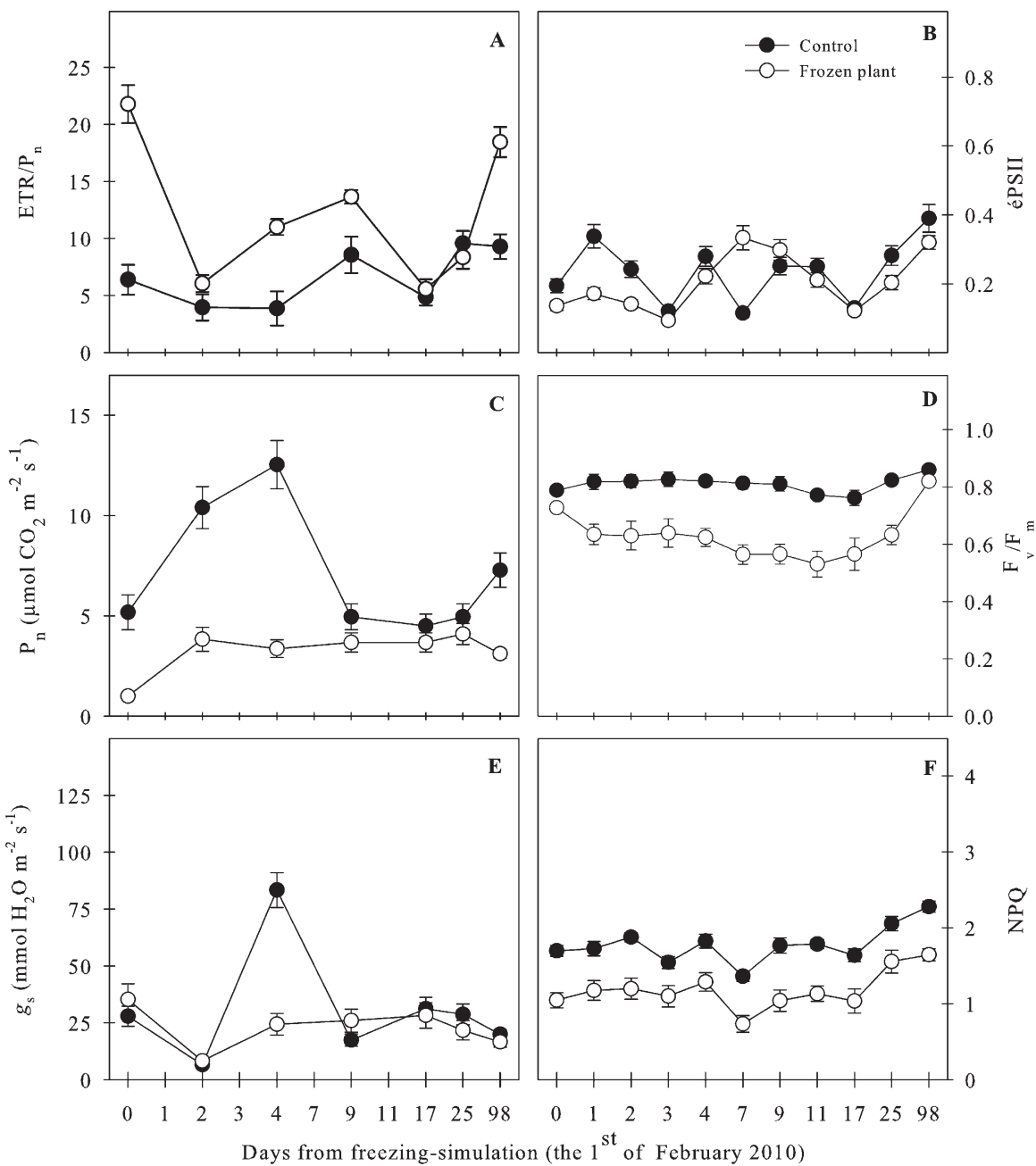

Fig. 3. Photochemical and gas exchange parameters in N. oleander 'Pink' leaves after freezing simulation applied on 1 Feb. 2010. (A) Ratio between apparent electron transport rate and net photosynthesis $\left(E T R / P_{n}\right)$; (B) quantum yield of photosystem II (éPSII); (C) net photosynthesis $\left(\mathrm{P}_{\mathrm{n}}\right)$; (D) maximum photochemical efficiency of PSII $\left(\mathrm{F}_{\mathrm{v}} / \mathrm{F}_{\mathrm{m}}\right) ;(\mathbf{E})$ stomatal conductance $\left(g_{\mathrm{S}}\right) ;(\mathbf{F})$ non-photochemical quenching (NPQ). Vertical bars indicate SE $(n=5)$.

occasion $4 \mathrm{~d}$ after freezing temperature application (Fig. 3E). This was probably as a result of an increase in the mean temperature (Fig. 2B), the non-frozen plants responding to this higher temperature, whereas the frozen plants did not because they were damaged.

To verify whether the frozen plants were photochemically damaged, the $\mathrm{F}_{\mathrm{v}} / \mathrm{F}_{\mathrm{m}}$ and ETR $/ \mathrm{P}_{\mathrm{n}}$ ratios were analyzed. At Day $0, \mathrm{~F}_{\mathrm{v}} /$ $F_{m}$ in both control and frozen plants was 0.79 and 0.74 , respectively. These values are below the 0.83 regarded as the optimal value for most plant species (Johnson et al., 1993), indicating decreased photochemical efficiency of PSII (Willits and Peet, 2001; Yamada et al., 1996). In control plants, the $F_{v} / F_{m}$ value of 0.79 might be associated with photoprotective mechanisms activated by a cold winter (Osmond et al., 1999) (Fig. 2B), because the photochemical process declines with cold (Arena et al., 2008; Huner et al., 1993), and the light energy received is excessive for their needs. ETR $/ \mathrm{P}_{\mathrm{n}}$ in control plants was 6.5 , a value close to the theoretical value (4.5) proposed by Krall and Edwards (1992), which suggests the appropriate use of electrons for photosynthetic $\mathrm{CO}_{2}$ fixation (Percival and Henderson, 2003). However, the decreased $\mathrm{F}_{\mathrm{v}} / \mathrm{F}_{\mathrm{m}}$ observed in frozen plants suggests that the leaf photosynthetic system was injured, and the high ETR/P $\mathrm{P}_{\mathrm{n}}$ (Fig. $3 \mathrm{~A}$ ) indicates that there was a substantial degree of electron transport to acceptors other than $\mathrm{CO}_{2}$. In the days after the frost, the frozen plants presented higher ETR $/ \mathrm{P}_{\mathrm{n}}$ values than control plants (Fig. $3 \mathrm{~A}$ ), whereas the $\mathrm{F}_{\mathrm{v}} / \mathrm{F}_{\mathrm{m}}$ ratio fell to reach 0.5 (Fig. 3D). Both ratios indicate that the photosynthetic apparatus of the pink oleander was injured. However, the former is more complicated to measure that the latter, because two instruments are needed to make each measurement. We suggest that $F_{v} / F_{m}$ can be considered an effective indicator of freezing injury in oleander, in which 0.6 could be considered a threshold to indicate freezing temperature damage. Other authors have proposed an $\mathrm{F}_{\mathrm{v}} / \mathrm{F}_{\mathrm{m}}$ threshold as an indicator of grapevine bud mortality by freezing temperatures (Zulini et al., 2010). However, at Day 120 post-treatment, the frozen plants presented $\mathrm{F}_{\mathrm{v}} / \mathrm{F}_{\mathrm{m}}$ values very close to 0.85 , indicating full

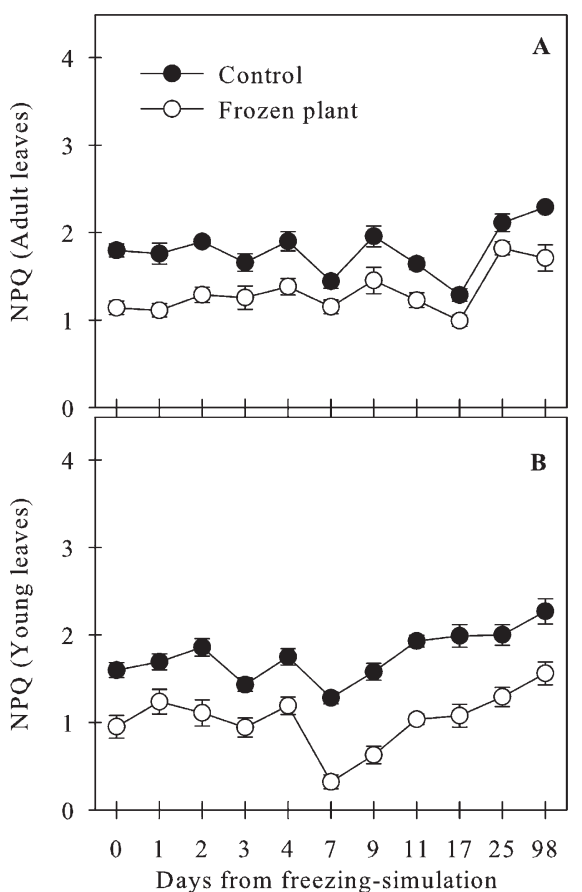

(1 February 2010)

Fig. 4. Non-photochemical quenching (NPQ) in $N$. oleander 'Pink'. (A) Adult leaves; (B) young leaves. Vertical bars indicate SE $(\mathrm{n}=5)$.

recovery of the leaf photosynthetic system, whereas ETR $/ \mathrm{P}_{\mathrm{n}}$ remained high (Fig. 3A). Percival (2005) also observed $F_{v} / F_{m}$ recovery several weeks after stress treatments (salinity, head, and herbicide) in oak. However, this recovery of the $\mathrm{F}_{\mathrm{v}} / \mathrm{F}_{\mathrm{m}}$ did not imply photosynthetic recovery (Fig. 3C). During spring, éPSII (Fig. 3C) and $F_{v} / F_{m}$ (Fig. 3B) increased in the frozen plants, indicating an increase in both current photochemical production and the intrinsic efficiency of PSII. However, the increase in the ETR/ $\mathrm{P}_{\mathrm{n}}$ ratio indicates that this photochemical production was hardly used for photosynthesis because it was dissipated in photorespiration and other photochemical processes (Foyer et al., 1994).

In this study, the frozen and non-frozen plants showed similar trends in NPQ, although of lower magnitude in the latter (Fig. 3F), which indicates that thermal dissipation mechanism was maintained in the former but diminished in the latter as a result of freezing. Lurie et al. (1994) reported a decrease in both the NPQ and the maximal fluorescence/basal fluorescence ratio $\left(\mathrm{F}_{\mathrm{m}} / \mathrm{F}_{\mathrm{o}}\right)$ in green peppers stored at $2{ }^{\circ} \mathrm{C}$; however, the response in NPQ to low temperature correlated more closely with visible chilling injury (CI) symptoms than $\mathrm{F}_{\mathrm{m}} / \mathrm{F}_{\mathrm{o}}$. Unlike the $\mathrm{F}_{\mathrm{v}} / \mathrm{F}_{\mathrm{m}}$ ratio, the NPQ remained lower in frozen plants $120 \mathrm{~d}$ after freezing simulation than in non-frozen plants (Fig. 3F). So, a decrease in NPQ was related to photodamage in the pink oleander, whereas an increase in NPQ was related to photoprotection of the photosynthetic apparatus in Beta vulgaris (D'Ambrosio et al., 2006) and two species of Lycopersicon (Venema et al., 2000) submitted to chilling 


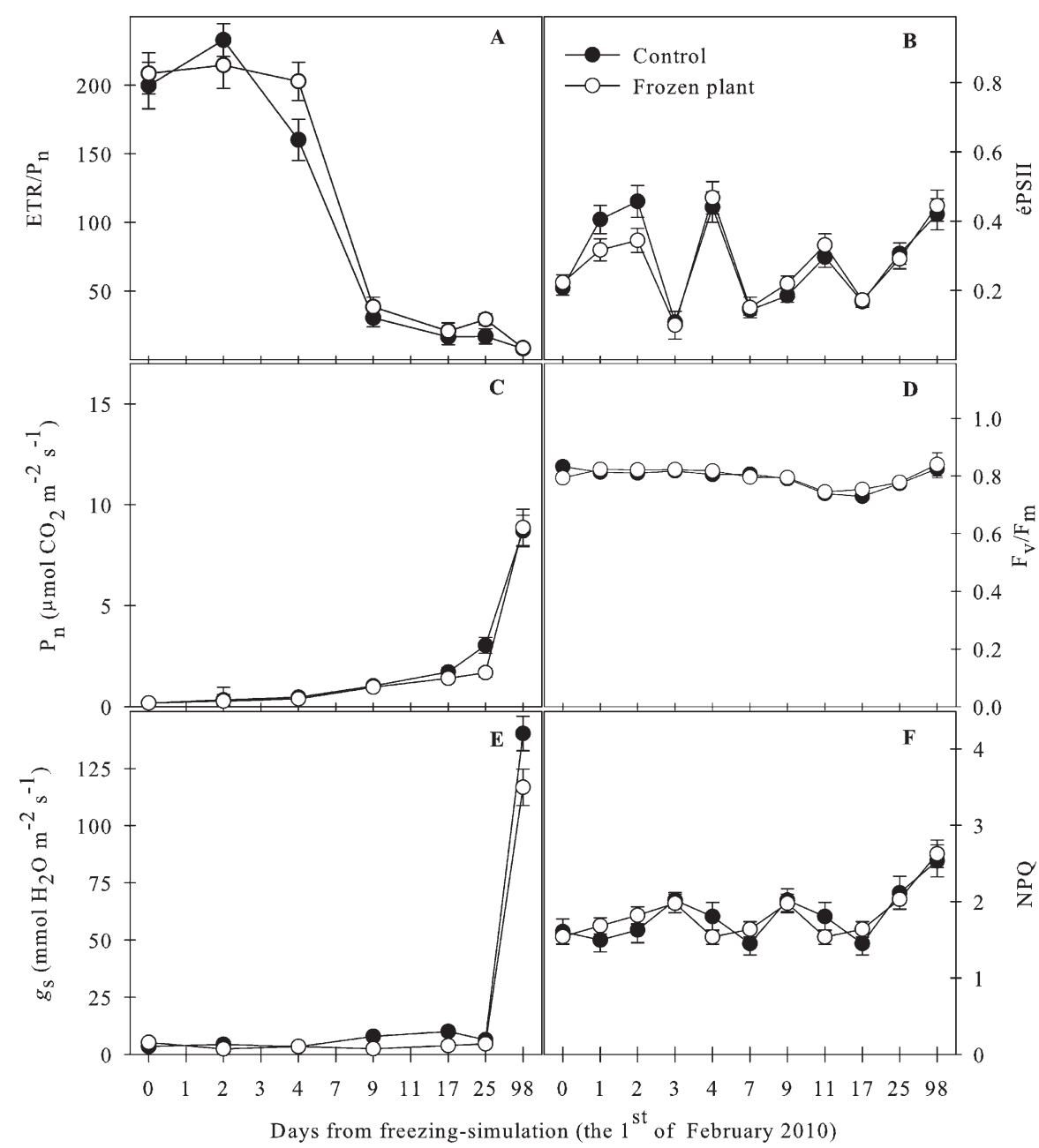

Fig. 5. Photochemical and gas exchange parameters in N. oleander 'Yellow' leaves after freezing simulation applied on 1 Feb. 2010. (A) Ratio between apparent electron transport rate and net photosynthesis $\left(\mathrm{ETR} / \mathrm{P}_{\mathrm{n}}\right)$; (B) quantum yield of photosystem II (éPSII); (C) net photosynthesis $\left(\mathrm{P}_{\mathrm{n}}\right)$; (D) maximum photochemical efficiency of PSII $\left(\mathrm{F}_{\mathrm{v}} / \mathrm{F}_{\mathrm{m}}\right)$; (E) stomatal conductance $\left(g_{\mathrm{S}}\right) ;(\mathbf{F})$ nonphotochemical quenching (NPQ). Vertical bars indicate SE $(n=5)$.

temperatures during high light. However, an increase in NPQ was observed at the end of the experiment in both oleander cultivars, which seems to be a result of an increasing $\mathrm{F}_{\mathrm{v}} / \mathrm{F}_{\mathrm{m}}$ (Figs. 3D and $\mathrm{F}$ ) because a change in $\mathrm{F}_{\mathrm{v}} / \mathrm{F}_{\mathrm{m}}$ is the result of a change in the efficiency of NPQ (Maxwell and Johnson, 2000). In this experiment, the young leaves (the most affected) showed a greater magnitude of difference in NPQ between frozen and non-frozen plants than adult leaves (Fig. 4), suggesting that this magnitude could indicate the level of injury caused by freezing.

The yellow oleander was apparently little injured by freezing (Table 1), confirming the greater freezing temperatures resistance of this cultivar. The absence of visual injury resulted in similar values for the photochemical and gas exchange parameters in the frozen and non-frozen plants (Fig. 5), indicating that the freezing temperatures did not injure the photosynthetic apparatus in the yellow cultivar. This demonstrates the sensitivity of chlorophyll fluorescence to identify physiological injury by freezing in oleander. Other authors have even found that fluorometry can be used to measure CI before tissue injury is visible in green peppers (Lurie et al., 1994).

\section{Conclusion}

In response to freezing stress in oleander, changes were observed in chlorophyll fluorescence when the frozen plants showed clear signs of injury. The decrease in NPQ and $\mathrm{F}_{\mathrm{v}} / \mathrm{F}_{\mathrm{m}}$ was closely related to freezing injury in pink oleander. The differences in NPQ between frozen and unfrozen plants were quite constant, even in spring. However, the $F_{v} / F_{m}$ of frozen plants recovered to reach the control value in spring, so that this can be only used in the first month after frost. These findings suggest that chlorophyll fluorescence offers considerable potential for speeding up the quantitative assessment of freezing injury in oleander, because it is rapid (especially $F_{v} / F_{m}$ ), sensitive, non-destructive, and relatively inexpensive.

\section{Literature Cited}

Adams, W.W. III, A. Hoehn, and B. DemmigAdams. 1995. Chilling temperatures and the xanthophyll cycle. A comparison of warm-grown and overwintering spinach. Aust. J. Plant Physiol. 22:75-85.

Allen, D.J. and D.R. Ort. 2001. Impacts of chilling temperatures on photosynthesis in warm-climate plants. Trends Plant Sci. 6:36-42.

Arena, C., L. Vitale, and A. Virzo De Santo. 2008. Photosynthesis and photoprotective strategies in Laurus nobilis L. and Quercus ilex L. under summer drought and winter cold. Plant Biosyst. 142:472-479.

Bilger, W. and O. Björkman. 1990. Role of xanthophyll cycle in photoprotection elucidated by measurements of light-induced absorbance changes, fluorescence and photosynthesis in Hedera canariensis. Photosynth. Res. 25:173-185.

D'Ambrosio, N., C. Arena, and A.V. De Santo. 2006. Temperature response of photosynthesis, excitation energy dissipation and alternative electron sinks to carbon assimilation in Beta vulgaris L. Environ. Exp. Bot. 55:248-257.

Forney, C.F., M.A. Jordan, and K. Nicholas. 2000 Volatile emissions and chlorophyll fluorescence as indicators of freezing injury in apple fruit. HortScience 35:1283-1287.

Foyer, C.H., M. Lelandais, and K.J. Kunert. 1994. Photooxidative stress in plants. Physiol. Plant. 92:696-717.

Genty, B., J.-M. Briantais, and N.R. Baker. 1989. The relationship between the quantum yield of photosynthetic electron transport and quenching of chlorophyll fluorescence. Biochim. Biophys. Acta 990:87-92.

Hakam, N., S. Khanizadeh, J.R. Deell, and C. Richer. 2000. Assessing chilling tolerance in pinks using chlorophyll fluorescence. HortScience 35:184-186.

Hetherington, S.E., R.M. Smillie, A.K. Hardacre, and H.A. Eagles. 1983. References using chlorophyll fluorescence in vivo to measure the chilling tolerance of different populations of maize. Aust. J. Plant Physiol. 10:247-256.

Horton, P., A.V. Ruban, and R.G. Walters. 1996. Regulation of light harvesting in green plants. Annu. Rev. Plant Physiol. Plant Mol. Biol. 47: 655-684.

Huner, N.P.A., G. Öquist, V.M. Hurry, M. Krol, S. Falk, and M. Griffith. 1993. Photosynthesis, photoinhibition and low temperature acclimation in cold tolerant plants. Photosynth. Res. 37:19-39.

Huner, N.P.A., G. Öquist, and F. Sarhan. 1998. Energy balance and acclimation to light and cold. Trends Plant Sci. 3:224-230.

Johnson, G.N., A.J. Young, J.D. Scholes, and P. Horton. 1993. The dissipation of excess excitation energy in British plant species. Plant Cell Environ. 16:673-679.

Krall, J.P. and G.E. Edwards. 1992. Relationship between photosystem II activity and $\mathrm{CO} 2$ fixation in leaves. Physiol. Plant. 86:180-187.

Khanizadeh, S., J.R. Deell, and N. Hakam. 2000. Evaluation of the spring frost susceptibility of strawberry genotypes using chlorophyll fluorescence measurements. HortScience 35:389.

Lurie, S., R. Ronen, and S. Meier. 1994. Determining chilling injury induction in green peppers using non-destructive pulse amplitude modulated (PAM) fluorometry. J. Amer. Soc. Hort. Sci. 119:59-62.

Maxwell, K. and G.N. Johnson. 2000. Chlorophyll fluorescence-A practical guide. J. Expt. Bot. 51:659-668.

Osmond, C.B. 1994. What is photoinhibition? Some insights from the comparison of shade and sun plants, p. 1-24. In: Baker, N.R. and J.R. Bowyer (eds.). Photoinhibition of photosynthesis - From molecular mechanisms to the field. BIOS Scientific Publishers Limited, Oxford, UK. 
Osmond, C.B., J.M. Anderson, M.C. Ball, and J.J.G. Egerton. 1999. Compromising efficiency: The molecular ecology of light-resource utilization in plants, p. 1-24. In: Press, M.C., J.D. Scholes, and M.G. Barker (eds.). Physiological plant ecology. Blackwell Science, Oxford, UK.

Percival, G.C. 2005. The use of chlorophyll fluorescence to identify chemical and environmental stress in leaf tissue of three oak (Quercus) species. J. Arboric. 31:215-227.

Percival, G.C. and G.A. Fraser. 2001. Measurement of the salinity and freezing tolerance of crataegus genotypes using chlorophyll fluorescence. J. Arboric. 27:233-245.

Percival, G.C., G.A. Fraser, and G. Oxenham. 2003. Foliar salt tolerance of Acer genotypes using chlorophyll fluorescence. J. Arboric. 29:61-66.

Percival, G.C. and A. Henderson. 2003. An assessment of the freezing tolerance of urban trees using chlorophyll fluorescence. J. Hortic. Sci. Biotechnol. 78:254-260.

Percival, G.C. and C.N. Sheriffs. 2002. Identification of drought-tolerant woody perennials using chlorophyll fluorescence. J. Arboric. 28:215-223.

Smillie, R.M. and S.E. Hetherington. 1983. Stress tolerance and stress induced injury in crop plants measured by chlorophyll fluorescence in vivo. Plant Physiol. 72:1043-1050.

Smillie, R.M. and R. Nott. 1979. Assay of chilling injury in wild and domestic tomatoes based on photosystem activity of chilled leaves. Plant Physiol. 63:796-801.

Sthapit, B.R., J.R. Witcombe, and J.M. Wilson. 1995. Methods of selection for chilling tolerance in nepalese rice by chlorophyll fluorescence analysis. Crop Sci. 35:90-94.

Venema, J.H., L. Villerous, and P.R. van Hasselt. 2000. Effect of acclimation to suboptimal temperature on chilling-induced photodamage:
Comparison between a domestic and highaltitude wild Lycopersicon species. Plant Sci. 152:153-163.

Willits, D.H. and M.M. Peet. 2001. Using chlorophyll fluorescence to model leaf photosynthesis in greenhouse pepper and tomato. Acta Hort. 507:311-315.

Wilson, J.M. and J.A. Greaves. 1990. Assessment of chilling sensitivity by chlorophyll fluorescence analysis, p. 129-141. In: Wang, C.Y. (ed.). Chilling injury of horticultural crops. CRC Press, Boca Raton, FL.

Yamada, M., T. Hidaka, and H. Fukamachi. 1996. Heat tolerance in leaves of tropical fruit crops as measured by chlorophyll fluorescence. Sci. Hort. 67:39-48.

Zulini, L., C. Fischer, and M. Bertamini. 2010. Chlorophyll fluorescence as a tool for evaluation of viability in freeze-stressed grapevine buds. Photosynthetica 48:317-319. 